\title{
Anti-allergic Effect of Bee Venom in an Allergic Rhinitis Mouse Model
}

\author{
Seung-Heon Shin, ${ }^{*}, a \dagger$ Yee-Hyuk Kim, ${ }^{a}$ Jeong-Kyu Kim, ${ }^{a}$ and Kwan-Kyu Park ${ }^{b}$ \\ ${ }^{a}$ Department of Otolaryngology-Head and Neck Surgery, Catholic University of Daegu; and ${ }^{b}$ Department of \\ Pathology, School of Medicine, Catholic University of Daegu; Daegu 705-718, Korea. \\ Received January 29, 2014; accepted May 28, 2014
}

Bee venom (BV) has been used as an anti-inflammatory and immune modulating agent in Oriental medicine. This study used a mouse model to investigate the anti-allergic effect of $\mathrm{BV}$, which is used in the treatment of various inflammatory diseases in traditional medicine. BV was obtained from the National Institute of Agricultural Science and Technology of Korea. Female BALB/C mice were sensitized by intraperitoneal injection of ovalbumin (OVA). BV was administered nasally prior to the intranasal instillation of OVA. Allergic behavior, serum OVA-specific immunoglobulin E (IgE), interleukin (IL)-4, IL-10, and interferon-gamma $(\mathrm{INF}-\gamma)$ levels in nasal lavage fluid were measured. Hematoxylin-eosin and periodic acid-Schiff staining were performed to evaluate histological change. BV attenuated nasal symptoms and inhibited the production of OVA-specific IgE and IL-4 in sensitized mice. The degree of inflammatory cell infiltration and goblet cell hyperplasia was attenuated by BV. Thus, BV effectively reduced allergic inflammation in a mouse model of allergic rhinitis, suggesting its potential as a useful therapeutic agent to treat allergic rhinitis.

Key words bee venom; allergic rhinitis; ovalbumin; mouse model

Allergic rhinitis (AR) is characterized by nasal mucosal inflammation resulting from immunoglobulin $\mathrm{E}$ (IgE) mediated hypersensitivity reaction. Allergen exposures stimulate infiltration of inflammatory cells within the nasal mucosa, including basophils, eosinophils, mast cells, and mononuclear cells. These inflammatory cells release several allergic mediators, such as histamine, cysteinyl leukotrienes, and prostaglandins, which sustain the inflammatory reaction and produce characteristic nasal symptoms of, sneezing, itching, rhinorrhea and nasal congestion. Animal models of the allergic response to inhaled allergens have been studied to elucidate the mechanisms leading to the development of inflammation and the therapeutic effect of newly developed anti-inflammatory agents. Repeated exposure of mice to ovalbumin (OVA) has been used to develop an allergic model with inflammatory cell infiltration and increased thickness of the epithelial layer. ${ }^{1)}$

Bee venom (BV) consists of a various biologically active amines, peptides and nonpeptide components, and has radioprotective, antimutagenic, anti-inflammatory, antinociceptive, and anticancer activities. ${ }^{2,3)}$ Two main components of BV, melittin and adolapin, have anti-inflammatory activity that involve inhibition of cycloxygease- 2 and, phospholipase $\mathrm{A}_{2}$ expression, and decrease levels of tumor necrosis factor- $\alpha$, interleukin (IL)-1, IL-6, and nitric oxide. ${ }^{4)}$ The anti-allergic activity is associated with marked inhibition of OVA-induced tracheal contraction and histamine release from lung tissue. The mast-cell degranulating peptide binds to the mast cell receptors and inhibits the binding of $\operatorname{IgE}$ and production of histamine. ${ }^{5)} \mathrm{BV}$ also inhibits the release of inflammatory mediators similar to nonsteroidal anti-inflammatory drugs.

The anti-inflammatory effect of BV includes airborne allergen-induced cytokine production from nasal epithelial cells. ${ }^{6,7)}$ Depending on the type of treated cells, BV can exhibit time and dose dependent immunosuppressive and/or immunostimu-

\footnotetext{
The authors declare no conflict of interest.

${ }^{\dagger}$ Present address: Department of Otorhinolaryngology, Daegu Catholic University Medical Center; 33 Duryugongwon-ro 17-gil, Nam-Gu, Daegu 705-718, South Korea.
}

* To whom correspondence should be addressed. e-mail: hsseung@cu.ac.kr lant activity. Given the anti-inflammatory effect of BV, it can also paradoxically cause a severe allergic or inflammatory reaction, depending on the administered concentration. Thus, the optimal concentration and dosage should be determined before clinical application of BV as a therapeutic agent. In this study, we used a mouse model of allergy rhinitis to evaluate the effect of BV instillation on nasal mucosal inflammation and allergic symptoms.

\section{MATERIALS AND METHODS}

Preparation of BV Pure honeybee (Apis mellifera) venom was obtained from the National Institute of Agricultural Science and Technology, Suwon, Korea. BV was collected using a specialized collector without damaging the honeybee by an established electric shock method. BV was dissolved in distilled water and centrifuged at $12000 \times \boldsymbol{g}$ for $10 \mathrm{~min}$ to remove insoluble materials. The BV was lyophilized by freeze drying and stored. ${ }^{8)}$

Animals and Experimental Protocol Female BALB/c mice, which were six-weeks old and free of murine specific pathogens, were obtained from Hyosung Science (Daegu, South Korea). They were maintained under standard laboratory conditions in a pathogen-free cage. Food and water were freely available and all animal experiments in this study were conducted in accordance with the guidelines of the Institutional Review Board of Daegu Catholic University Medical Center.

Mice were sensitized by administration of an intraperitoneal injection of OVA $(75 \mu \mathrm{g})$ in $200 \mu \mathrm{L}$ of phosphate buffer solution (PBS) containing $2 \mathrm{mg}$ of aluminum hydroxide (SigmaAldrich, St. Louis, MO, U.S.A.) in a total volume of $200 \mu \mathrm{L}$ on days $0,7,14$, and 21 . On days 22-30 after initial sensitization, mice were challenged with nasal instillation of OVA $500 \mu \mathrm{g}$ in $20 \mu \mathrm{L}$ of PBS into bilateral nasal cavities. The control group was sensitized and challenged with PBS instead of OVA (Fig. 1). BV was dissolved in PBS and nasally administered by micropipette $(20 \mu \mathrm{L}$ at $0.05,0.5,5$, and $10 \mathrm{ng} / \mathrm{mL})$, beginning $1 \mathrm{~h}$ before each challenge on days 22-30. The control group was 


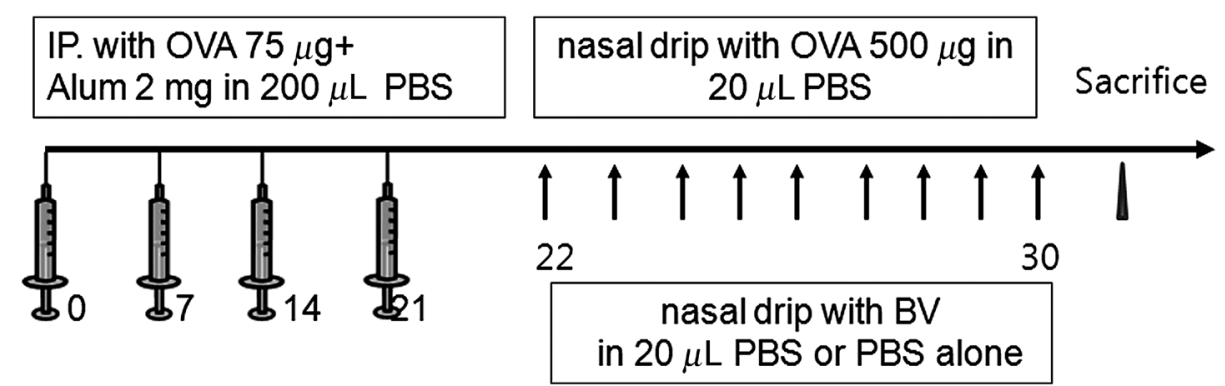

Fig. 1. Schematic Diagram of Ovalbumin (OVA) Induced Allergic Rhinitis Model

BALB/c mice were sensitized with OVA and aluminum hydroxide on days $0,7,14$, and 21 . All groups except the negative control were sensitized with intranasal instillation with OVA on days 22 to 30 . BV was nasally administered $1 \mathrm{~h}$ before each challenge at $0.05,0.5,5$, and $10 \mathrm{ng} / \mathrm{mL}$ on days $22-30$. Positive control group was treated with phosphate buffered saline.

treated with PBS.

Evaluation of Nasal Symptoms The number of sneezing and nose rubbing motions for $15 \mathrm{~min}$ after the final allergen challenge was recorded and compared with that of the control group.

Nasal Lavage Fluid Collection Nasal lavage fluid was collected $24 \mathrm{~h}$ after the last intranasal provocation with OVA. Nasal lavage by an 18-gauge catheter was performed after partial tracheal resection. The catheter was inserted into the tracheal opening in the direction of the upper airway and into the nasopharynx. Nasal passages were gently perfused with $1 \mathrm{~mL}$ cold PBS and collected in a tube. The collected fluid was centrifuged at $2000 \mathrm{rpm}$ for $7 \mathrm{~min}$ at $4^{\circ} \mathrm{C}$, and the supernatant was stored at $-70^{\circ} \mathrm{C}$. Amounts of IL-4, IL-10 and interferongamma (INF- $\gamma$ ) in nasal lavage fluid were measured using an ELISA quantitation kit (R\&D Systems, Minneapolis, MN, U.S.A.).

Measurement of OVA-Specific IgE in Serum Blood specimens were collected from the inferior vena cava $24 \mathrm{~h}$ after the last intranasal provocation. Serum was obtained by centrifugation and stored at $-70^{\circ} \mathrm{C}$. OVA-specific IgE level in serum was measured using ELISA (Pharmingen, San Diego, CA, U.S.A.).

Histological Evaluation of Nasal Mucosa Mice were painlessly sacrificed with a lethal dose $(120 \mathrm{mg} / \mathrm{kg})$ of intraperitoneally administered pentobarbital sodium $24 \mathrm{~h}$ after the last intranasal provocation. Decapitated heads were immersed in $10 \%$ neutral formalin overnight. The heads were then stripped of the eyes, skin, muscle, and the mandibles were excised. Specimens were decalcified until they were soft in $0.25 \mathrm{~mol} / \mathrm{L}$ ethylenediaminetetraacetic acid for $24 \mathrm{~h}$. The heads were trimmed with a fresh razor blade, with excision of the anterior portion of the nose and brain, leaving a portion of the nasal sinus, which measured approximately $8 \mathrm{~mm}$ in length from anterior to posterior. The resulting blocks were embedded in paraffin and sectioned anterior to posterior at $5-\mu \mathrm{m}$ thickness.

Three anatomically similar sections were chosen from each mouse for analysis. The first section, the most anterior, was at the level of the maxillary sinuses. The second section, more posterior, was at the end of the maxillary sinuses and the beginning of the complex ethmoid turbinals. The third section, most posterior, contained the brain superiorly.

Appearance of inflammatory cell infiltration and epithelial thickness was quantified in hematoxylin and eosin stained sections at $\times 200$ and $\times 400$ magnification. Goblet cell numbers were quantified in periodic acid Schiff (PAS) stain at $\times 200$ magnification. All tissue sections were examined blindly with respect to the source of the tissue and counts were determined at three different mucosal areas for each of the three sections per mouse.

The presence or absence of submucosal inflammatory cell infiltration was quantified into four categories -0 : no, 1: mild, occasional scattered inflammatory cells, 2: moderate, 3: severe, diffuse infiltration of inflammatory cells. Epithelial thickness was directly measured on a scale of $\times 400$ magnification and average number of goblet cells was counted at four different areas per $\mathrm{mm}^{2}$ of nasal mucosa by an eyepiece reticule.

To determine the anti-inflammatory effect of BV, immunohistochemical staining was performed by using the avidin-biotin complex method. Deparaffinized sections were incubated with primary antibodies for $1 \mathrm{~h}$ at room temperature (nuclear factor (NF)- $\kappa \mathrm{B}$ p65, activator protein (AP)-1 c-Jun, Santa Cruz, CA, U.S.A.). Bounded antibody was visualized with avidin-biotin-peroxidase complex and color was developed by $3,3^{\prime}$-diaminobenzidine tetrahydrochloride. The morphometrical analysis was done with an image analyzer. A minimum of three sections were analyzed per mouse. Images were captured with a Nikon ECLIPSE 80i microscope (Nikon, Melville, NY, U.S.A.) and i-Solution (IMT i-Solution; ver. 11.0, Canada) was used to measure NF- $\kappa \mathrm{B}$ p 65 -positive, c-Junpositive area in epithelial area.

Statistical Analysis All measured parameters are expressed as mean \pm S.D. and are representative of five independent experiments. The Mann-Whitney $U$ test (SPSS Inc., Chicago, IL, U.S.A.) was performed for statistical analysis of data. A probability value less than 0.05 was considered statistically significant.

\section{RESULTS}

Allergic Behavior The mean behavior score (total number of sneezing and nasal rubbing motions for $15 \mathrm{~min}$ after the final challenge) was $6.2 \pm 3.5$ in the control group, $36.4 \pm 3.2$ in the AR group, $22.6 \pm 4.3$ in the $0.05 \mathrm{ng} / \mathrm{mL}$ of BV group, $4.3 \pm$ 1.4 in the $0.5 \mathrm{ng} / \mathrm{mL}$ group, $15.2 \pm 2.6$ in the $5 \mathrm{ng} / \mathrm{mL}$ group and $24.7 \pm 9.4$ in the $10 \mathrm{ng} / \mathrm{mL}$ group. Behavior scores were lower in the 0.5 and $5 \mathrm{ng} / \mathrm{mL} \mathrm{BV}$ groups, compared with the AR group $(p<0.05)$ (Fig. 2).

Nasal Lavage Fluid Cytokine and Serum OVA-Specific IgE Repeated intranasal administration of BV resulted in a 
significant decrease in serum OVA specific IgE antibody level at 0.5 and $5 \mathrm{ng} / \mathrm{mL}$ of BV $(p<0.05)$. At $10 \mathrm{ng} / \mathrm{mL}$ of BV, OVA specific IgE antibody level was similar with the non-treated AR group (Fig. 2). IL-4 and IL-10 levels in nasal lavage fluid displayed a significant increase in the AR group (14.9 \pm 5.2 , $12.6 \pm 4.7 \mathrm{pg} / \mathrm{mL}$, respectively), compared with the control group $(4.7 \pm 1.2,2.9 \pm 0.7 \mathrm{pg} / \mathrm{mL}$, respectively). IL-4 production was significantly inhibited by $\mathrm{BV}$ at $0.05,0.5$, and $5 \mathrm{ng} / \mathrm{mL}$ $(p<0.05)$. However, IL-10 and INF- $\gamma$ in nasal lavage fluid did not differ significantly among the AR, control, and BV treated group (Fig. 3).

Histological Changes Whereas no or minimal inflammation was noted in the control group, all experimental groups showed an increase in inflammatory cell infiltration of the

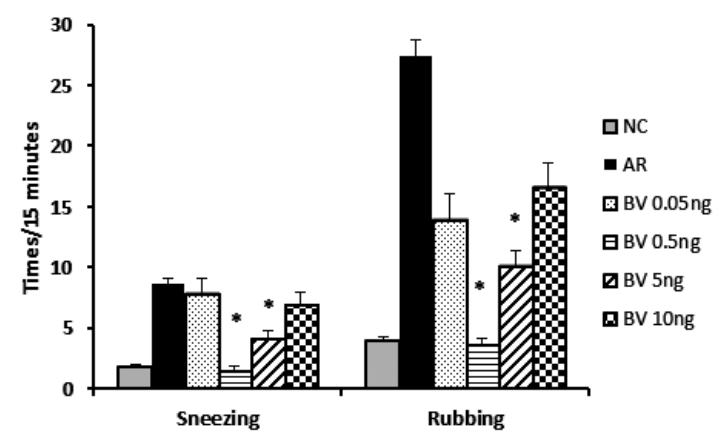

Fig. 2. Effects of Bee Venom (BV) on Allergy Symptoms in Ovalbumin (OVA) Induced Allergic Rhinitis Mouse Model

Total number of sneezing and nasal rubbing motions were significantly inhibited with BV at concentration 0.5 and $5 \mathrm{ng} / \mathrm{mL}$. NC; negative control, AR; non-treated allergic rhinitis, $* p<0.05$ vs. AR group. submucosal area. The degree of inflammatory cell infiltrations showed an increase in the AR group (1.7 \pm 0.4$)$. BV induced significant inhibition of inflammatory cell infiltration at $5 \mathrm{ng} /$ $\mathrm{mL}(0.9 \pm 0.3)$. Although at other concentrations of $\mathrm{BV}$, the inflammatory cell infiltration was not statistically significantly inhibited, BV tended to decrease the infiltration of inflammatory cells in nasal mucosa. Mean inflammatory cell infiltration scores were $1.2 \pm 0.4$ with $0.05 \mathrm{ng} / \mathrm{mL}, 1.3 \pm 0.3$ with $0.5 \mathrm{ng} / \mathrm{mL}$, and $1.1 \pm 0.5$ with $10 \mathrm{ng} / \mathrm{mL}$ of BV (Fig. 4).

Thickness of epithelial cells in nasal mucosa showed a significant increase in the AR group $(27.2 \pm 6.7 \mu \mathrm{m})$ compared with the control group $(16.3 \pm 4.7 \mu \mathrm{m})$. However, BV did not have a significant influence on the thickness of epithelial cells (Fig. 5).

To determine the change of mucin producing cells in nasal mucosa, PAS-positive cells were counted. Mucin producing goblet cells were significant increase in the AR group $\left(38.2 \pm 13.3\right.$ per $\left.\mathrm{mm}^{2}\right)$, compared with the control group (4.3 \pm 0.8 per $\mathrm{mm}^{2}$ ). Mucin producing cells were significantly decreased in OVA-sensitized mice treated with BV at concentrations of $0.5 \mathrm{ng} / \mathrm{mL} \quad\left(15.5 \pm 3.2\right.$ per $\left.\mathrm{mm}^{2}\right), \quad 5 \mathrm{ng} / \mathrm{mL} \quad(15.2 \pm$ 5.3 permm $\left.\mathrm{mm}^{2}\right)$, and $10 \mathrm{ng} / \mathrm{mL} \quad\left(12.1 \pm 3.7\right.$ permm $\mathrm{mm}^{2} \quad(p<0.05)$. However, $0.05 \mathrm{ng} / \mathrm{mL}$ BV did not have a significant influence on PAS-positive cells (24.8 \pm 13.2 per $\mathrm{mm}^{2}$ ) (Fig. 5).

To determine the anti-inflammatory mechanism of $\mathrm{BV}$, $\mathrm{NF}-\kappa \mathrm{B}$ and AP-1 expressions were determined with immunohiostochemical stain. NF- $\kappa \mathrm{B}$ expression was significantly suppressed with BV at concentrations of $0.5 \mathrm{ng} / \mathrm{mL}(48 \%)$, $5 \mathrm{ng} / \mathrm{mL}(41 \%)$, and $10 \mathrm{ng} / \mathrm{mL}(49 \%)(p<0.05)$. However, AP-1 expression was not significantly suppressed with BV (Fig. 6).
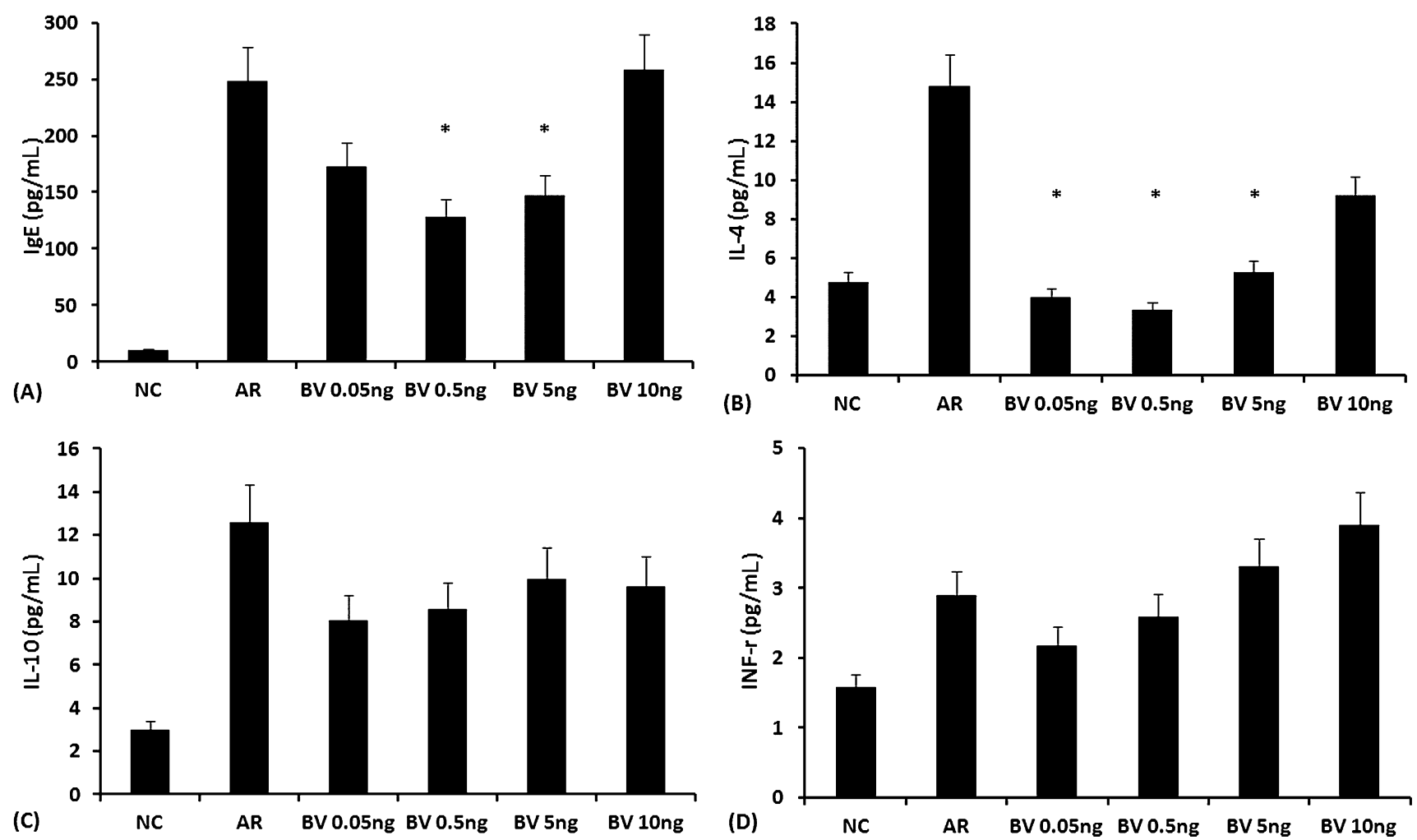

Fig. 3. Effects of Bee Venom (BV) on Production of Inflammatory Mediators in Ovalbumin (OVA) Induced Allergic Rhinitis Mouse Model

(A) OVA-specific IgE levels in serum and (B-D) interleukin (IL)-4, IL-10, and interferon (INF)- $\gamma$ in nasal lavage fluid after intranasal instillation of BV. OVA-specific IgE and IL-4 production was significantly inhibited by BV. The values are mean \pm S.D. of five independent experiments. NC; negative control, AR; non-treated allergic rhinitis, ${ }^{*} p<0.05$ vs. AR group. 


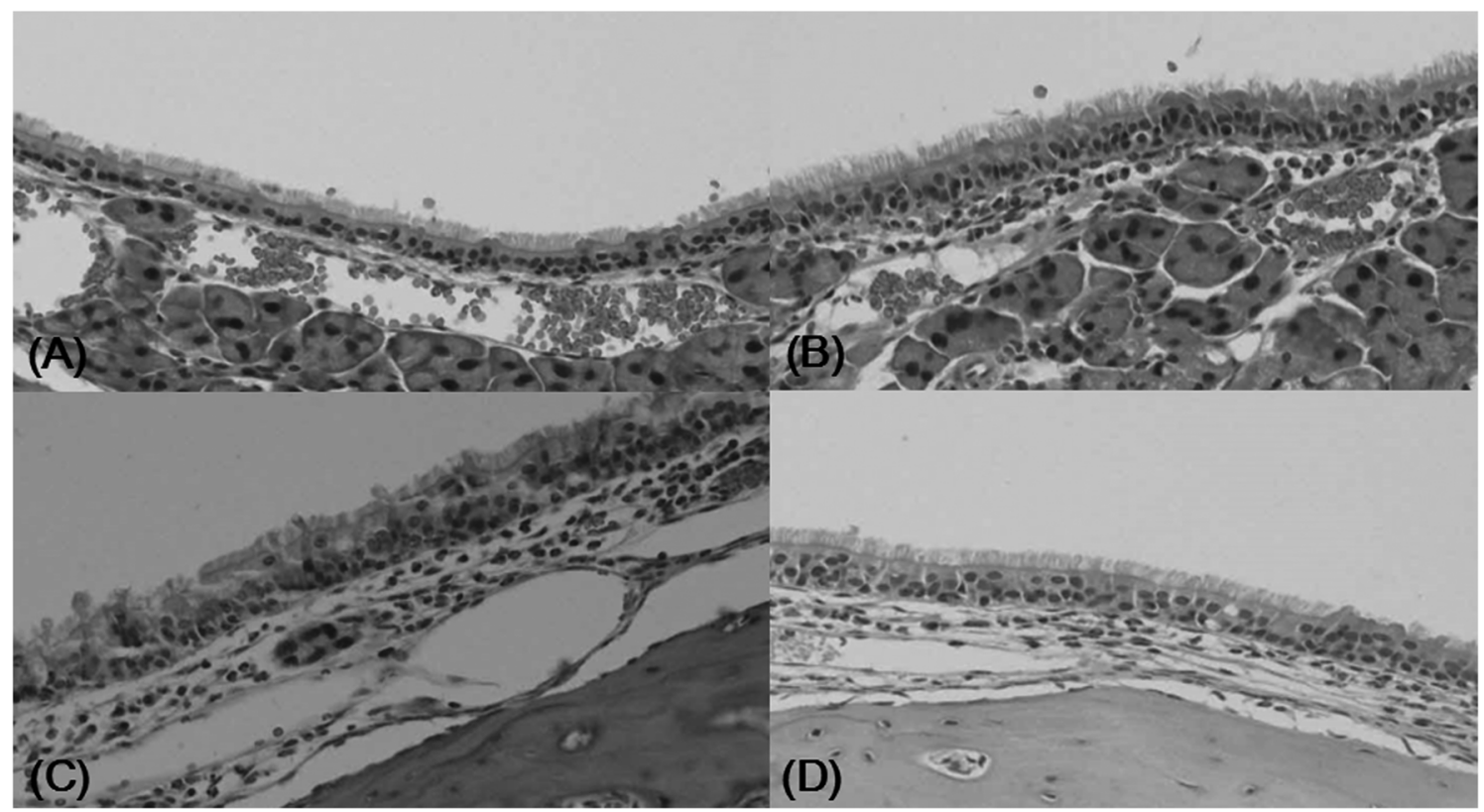

Fig. 4. Effects of Bee Venom (BV) on Inflammatory Cell Infiltration in Histologic Sections of Sinonasal Tissue of Ovalbumin (OVA) Induced Allergic Rhinitis Mouse Model (H\&E Stain, $\times 200)$

(A) Negative control tissue, (B) non-treated allergic rhinitis, (C) treated with $0.05 \mathrm{ng} / \mathrm{mL}$ of BV, and (D) treated with $5 \mathrm{ng} / \mathrm{mL}$ of BV. (B) shows inflammatory cells with eosinophils were infiltrated in subepithelial layer of sinus mucosa. (D) shows significantly decreased inflammatory cells infiltration.
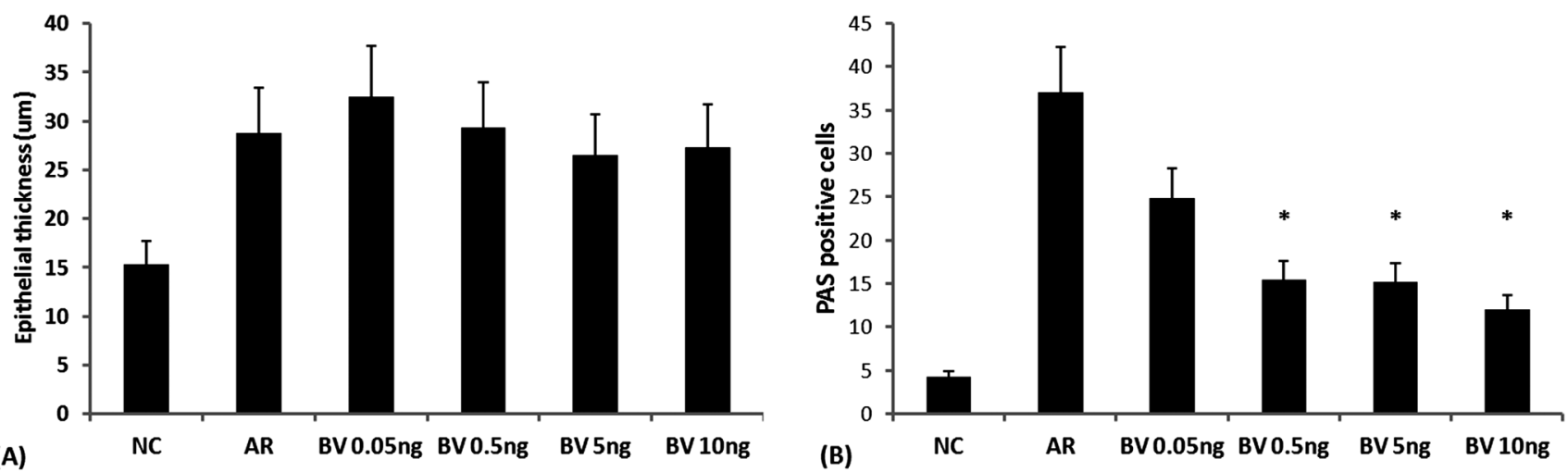

Fig. 5. Effects of Bee Venom (BV) on the Histological Change in Ovalbumin (OVA) Induced Allergic Rhinitis Mouse Model

Epithelial thickness and the number of periodic acid-Schiff (PAS) positive cells of nasal mucosa of each study group. (A) Epithelial thickness was not influenced by intranasal instillation of BV. (B) The number of PAS positive cells was decreased decrease at $0.5,5$, and $10 \mathrm{ng} / \mathrm{mL}$ of BV. The values are mean \pm S.D. of five independent experiments. NC; negative control, AR; non-treated allergic rhinitis, ${ }^{*} p<0.05 v s$. AR group.

\section{DISCUSSION}

$\mathrm{AR}$ is the most common chronic inflammatory condition within the nasal mucosa, affecting $10 \%$ to $30 \%$ of adults and $20 \%$ to $40 \%$ of children. ${ }^{9)}$ Chronic inflammation of the nasal mucosa is associated with pathophysiologic change in the epithelial cells, goblet cell hyperplasia, and inflammatory cell infiltration. The presentation of an allergen to lymphocytes leads to the release of Th2 cytokines, which promote IgE production and subsequent release of allergic inflammatory mediators, including histamine and leukotrienes from basophils and eosinophils. Pharmacological and immunological treatment modalities for allergy rhinitis include, antihistamines, corticosteroids, decongestants, mast cell stabilizers, leukotriene modifiers, anti-IgE antibodies, phophodiesterase inhibitors, intranasal heparin, and immunotherapy. Although these therapies are effective and safe, the search for more effective and safe way to conclusively alter the pattern of treatment of AR is desirable.
In this study, we used BV collected by electric shock method without scarifying the honey bees. BV concentrations ranging from 0.05 to $10 \mathrm{ng} / \mathrm{mL}$ did not influence the morphology of nasal mucosa and survival of mice. Although up to $3 \mu \mathrm{g} / \mathrm{mL}$ of $\mathrm{BV}$ is not reportedly cytotoxic to nasal epithelial cells, more than $500 \mathrm{ng} / \mathrm{mL}$ of $\mathrm{BV}$ is lethal to mouse. ${ }^{6}$ In this experiment, we used less than $10 \mathrm{ng} / \mathrm{mL}$ of BV. BV contains at least $18 \mathrm{ac}-$ tive components, including enzymes, peptides, and biogenic amines. Peptides of BV have anti-inflammatory effects due to their ability to inhibit prostaglandin synthesis, stabilize mast cells, and inhibit the activity of cyclooxygenase. ${ }^{10)}$ However, at higher concentrations of $\mathrm{BV}$, enzymatic components that enhance the inflammatory response might influence immune response. BV induces neurogenic inflammation and tissue edema due to the toxins containing in BV. ${ }^{11)}$ For use in humans, the optimal concentration of BV that exerts maximal anti-inflammatory effects without harmful effects must be determined. Although BV is heat-stable and strongly affects 


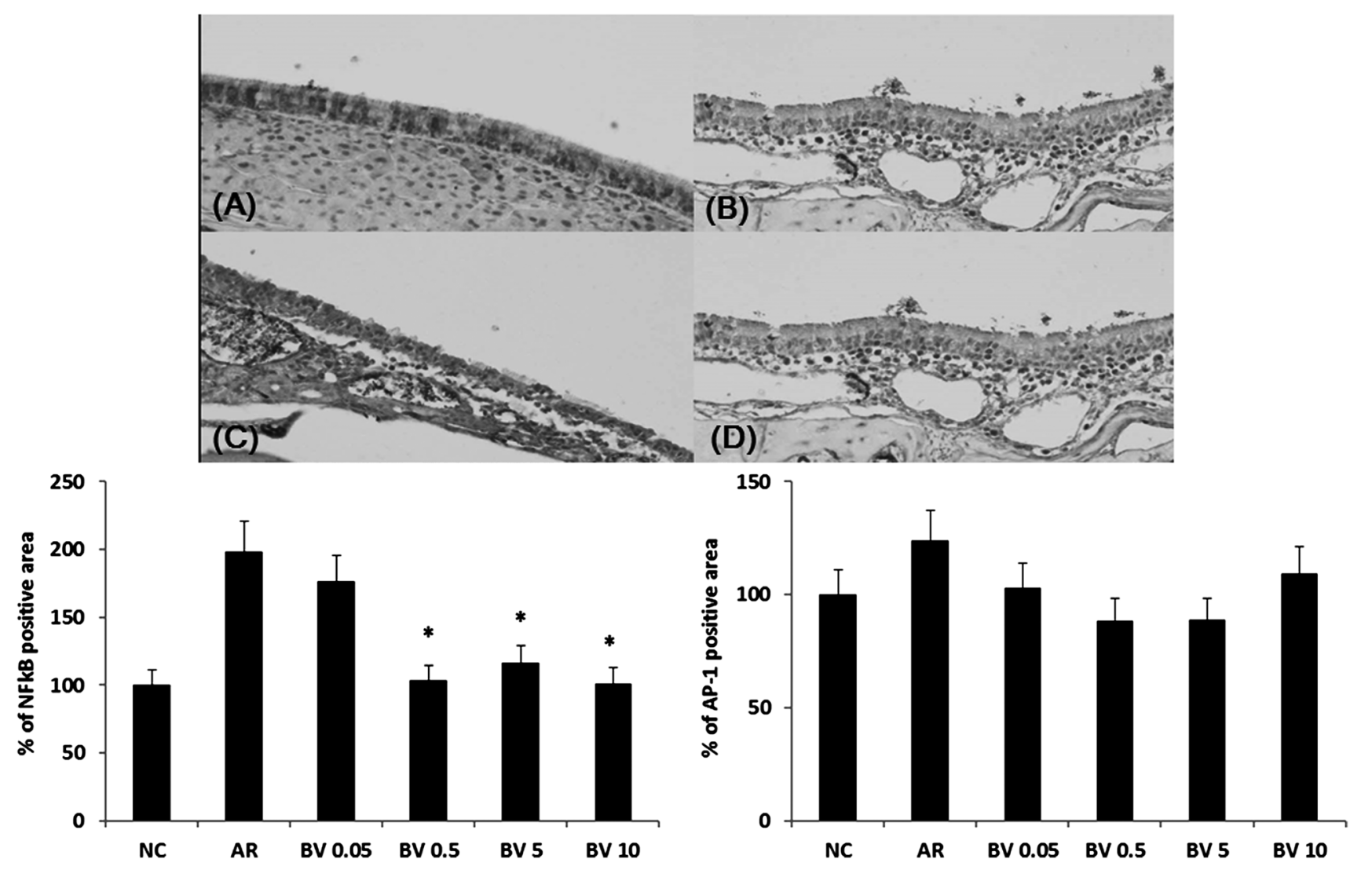

Fig. 6. Effects of Bee Venom (BV) on the Expression of Nuclear Factor (NF)- $\kappa \mathrm{B}$ and Activator Protein (AP)-1 in Immunohistochemical Section of Sinonasal Tissue of Ovalbumin (OVA) Induced Allergic Rhinitis Mouse Model $(\times 200)$

(A) and (B) show NF- $\kappa$ B expression of non-treated (A) and treated with $5 \mathrm{ng} / \mathrm{mL}$ of BV (B). (C) and (D) show AP- 1 expression of non-treated (C) and treated with $5 \mathrm{ng} /$ $\mathrm{mL}$ of BV (D). NF- $\kappa$ B expression was significantly suppressed with BV at concentrations of 0.5 , 5 , and $10 \mathrm{ng} / \mathrm{mL}(p<0.05)$. However, AP-1 expression was not significantly suppressed with $\mathrm{BV}$. NC; negative control, AR; non-treated allergic rhinitis, ${ }^{*} p<0.05 v s$. AR group.

the mucous membrane, BV components are easily weakened by digestive enzymes, such as pepsin, pancreatin, and lennin. Hence, oral administration is ineffective. Intranasal application was used in this study.

Although BV has anti-inflammatory characteristics, its antiallergic characteristic has not been commonly studied. Our previous study reported that BV inhibits airborne allergeninduced cytokine production from nasal epithelial cells by inhibiting the NF- $\kappa \mathrm{B}$ and AP-1 pathways. In vitro, the anti-allergic effect of BV has been demonstrated. Presently, we tried to confirm the anti-allergic properties of BV using a mouse model of AR. The model displayed characteristic allergic behaviors, tissue eosinophilia, and increased thickness of lamina propria and epithelium. ${ }^{12)} \mathrm{BV}$ decreased allergic symptom score, inflammatory cell infiltration of nasal mucosa, and PAS positive cell counts. Although the exact mechanism of the anti-allergic effect of BV was not determined, we can suggest several possible mechanisms. First, BV can inhibit the production of chemical mediators from nasal epithelial cells. These chemical mediators influence the accumulation of inflammatory cells and Th2 immune responses in nasal mucosa. BV suppresses leukocyte migration and reduces cytokine production upon uptake of the antigen by dendritic cells. ${ }^{13)}$ Second, BV inhibits the production of Th2 cytokines from lymphocytes. Phytohaemagglutinin and lipopolysaccharide induced TNF- $\alpha$ and INF- $\gamma$ production from peripheral blood mononuclear cells are significantly inhibited by $\mathrm{BV}^{14)}$ Although in-vitro study with nasal epithelial cells, anti-inflammatory effect of
BV was associated with the inhibition of NF- $\kappa$ B and AP-1 pathways, the anti-allergic effect of $\mathrm{BV}$ in mouse model was associated with the inhibition of NF- $\kappa$ B pathways. So, BV might induce an anti-inflammatory effect by the direct inhibition of transcription factors, such as NF- $\kappa \mathrm{B}$ or AP-1. Melittin, the major constituent of BV, inhibits the DNA-binding activity of NF- $\kappa \mathrm{B}$ by inhibiting $\mathrm{I} \kappa \mathrm{B}$ phosphorylation. Apamin inhibits both OVA-induced tracheal contraction and histamine release from lung tissue with a mast cell stabilizing effect. The mastcell-degranulating peptide binds to the mast cell receptors and partially inhibits the binding of IgE to its receptor. ${ }^{15)}$ Adolapin also has anti-inflammatory activity through its ability to inhibit prostaglandin synthesis. The eukaryotic transcription factor $\mathrm{NF}-\kappa \mathrm{B}$ is involved in the regulation of the arachidonic acid pathway.

In the present study, nasal instillation of BV inhibited OVA specific $\operatorname{IgE}$ antibody production in sensitized mice and the levels of Th2 cytokine and IL-4 in nasal lavage fluid. IL-10 is an anti-inflammatory cytokine produced by monocytes and, to a lesser extent, by lymphocytes. Although IL-10 concentration was not significantly decreased by BV treatment, production tended to decrease. IL-10 suppression may lead to up-regulation of Th1 cytokines like INF- $\gamma$, IL-3, and TNF. At 5 and $10 \mathrm{ng} / \mathrm{mL} \mathrm{BV}$, INF- $\gamma$ concentration in nasal lavage fluid was higher than in the non-treated group, suggesting that BV inhibits nasal allergic inflammation by inhibiting cytokine production from inflammatory or structural cells. However, intranasal application of BV did not influence the thickness 
of epithelial layer. In allergen induced inflammation, many mediators have been implicated in the tissue remodeling and structural change with thickness of the airway wall. ${ }^{1)}$ Th2 delivered cytokines are capable of inducing subepithelial fibrosis and TGF- $\beta$ also plays an important role in the progression of fibrotic events. The prolonged allergen challenge of sensitized mice results in persistent remodeling of the airway. In this study, BV inhibited the expression of IL-4 and inflammatory cell infiltration in allergen sensitized mice, it perhaps not sufficiently to suppress the fibrotic change or tissue remodeling process in nasal mucosa. The airway structural change is hard to reverse with anti-allergic medication. ${ }^{16}$

In summary, BV has significant anti-allergic effect in an animal model of human AR. The anti-allergy effect of BV is associated with the inhibition of Th2 cytokine production, inflammatory cell infiltration in nasal tissue and mucin production. The pharmacokinetics of the anti-allergic effect of BV has not been studied and is not fully understood. About $5 \mathrm{ng} /$ $\mathrm{mL}$ of $\mathrm{BV}$ is enough to control $\mathrm{AR}$ in this model. Although further studies are necessary prior to clinical use, BV may be a useful therapeutic strategy to treat AR due to the antiinflammatory effect. The combination of natural products, like $\mathrm{BV}$, with modern anti-allergic medications, might enhance the therapeutic potency and minimize adverse effects.

Acknowledgment This research was supported by the Basic Science Research Program through the National Research Foundation of Korea (NRF) funded by the Ministry of Education, Science and Technology (2010-0023163).

\section{REFERENCES}

1) McMillan SJ, Lloyd CM. Prolonged allergen challenge in mice leads to persistent airway remodeling. Clin. Exp. Allergy, 34, 497-507 (2004).

2) Son DJ, Lee JW, Lee YH, Song HS, Lee CK, Hong JT. Therapeutic application of anti-arthritis, pain-releasing, and anti-cancer effects of bee venom and its constituent compounds. Pharmacol. Ther., 115, 246-270 (2007).

3) Kim JI, Yang EJ, Lee MS, Kim YS, Huh Y, Cho IH, Kang S, Koh $\mathrm{HK}$. Bee venom reduces neuroinflammatin in the MPTP-induced model of Parkinson's disease. Int. J. Neurosci., 121, 209-217 (2011).

4) Shin JM, Jeong YJ, Cho HJ, Park KK, Chung IK, Lee IK, Kwak JY, Chang HW, Kim CH, Moon SK, Kim WJ, Choi YH, Chang YC. Melittin suppresses HIF-1 $\alpha /$ VEGF expression through inhibition of ERK and mTOR/p70S6K pathway in human cervical carcinoma cell. PLoS ONE, 8, e69380 (2013).

5) Buku A, Mendlowitz M, Condie BA, Price JA. Partial alanine scan of mast cell degranulating peptide (MCD): importance of the histidine-and arginine-residues. J. Pept. Sci., 10, 313-317 (2004).

6) Shin SH, Ye MK, Kim JK, Park KK. Bee venom at different concentrations modulates the aeroallergen-induced activation of nasal polyp epithelial cells. Pharmacology, 91, 39-47 (2013).
7) Shin SH, Ye MK, Kim JJ, Park KK. Bee venom reduces fungi induced bronchial epithelial cells activation through down regulation of NF- $\kappa$ B. Int. J. Pharmacol., 9, 143-149 (2013).

8) Han S, Lee K, Yeo J, Kweon H, Woo S, Lee M, Baek H, Kim S, Park K. Effect of honey bee venom on microglial cells nitric oxide and tumor necrosis factor-alpha production stimulated by LPS. $J$. Ethnopharmacol., 111, 176-181 (2007).

9) Bousquet J, Khaltaev N, Cruz AA, Denburg J, Fokkens WJ, Togias A, Zuberbier T, Baena-Cagnani CE, Canonica GW, van Weel C, Agache I, Aït-Khaled N, Bachert C, Blaiss MS, Bonini S, Boulet LP, Bousquet PJ, Camargos P, Carlsen KH, Chen Y, Custovic A, Dahl R, Demoly P, Douagui H, Durham SR, van Wijk RG, Kalayci O, Kaliner MA, Kim YY, Kowalski ML, Kuna P, Le LT, Lemiere C, Li J, Lockey RF, Mavale-Manuel S, Meltzer EO, Mohammad Y, Mullol J, Naclerio R, O’Hehir RE, Ohta K, Ouedraogo S, Palkonen S, Papadopoulos N, Passalacqua G, Pawankar R, Popov TA, Rabe KF, Rosado-Pinto J, Scadding GK, Simons FE, Toskala E, Valovirta E, van Cauwenberge P, Wang DY, Wickman M, Yawn BP, Yorgancioglu A, Yusuf OM, Zar H, Annesi-Maesano I, Bateman ED, Ben Kheder A, Boakye DA, Bouchard J, Burney P, Busse WW, ChanYeung M, Chavannes NH, Chuchalin A, Dolen WK, Emuzyte R, Grouse L, Humbert M, Jackson C, Johnston SL, Keith PK, Kemp JP, Klossek JM, Larenas-Linnemann D, Lipworth B, Malo JL, Marshall GD, Naspitz C, Nekam K, Niggemann B, NizankowskaMogilnicka E, Okamoto Y, Orru MP, Potter P, Price D, Stoloff SW, Vandenplas O, Viegi G, Williams D, World Health Organization, GA(2)LEN, AllerGen. Allergic rhinitis and its impact on asthma (ARIA) 2008 update (in collaboration with the World Health Organization, GA(2)LEN and AllerGen). Allergy, 63 (Suppl. 86), 8-160 (2008).

10) Nam KW, Je KH, Lee JH, Han HJ, Lee HJ, Kang SK, Mar W. Inhibition of COX-2 activity and proinflammatory cytokines (TNFalpha and IL-1 beta) production by water-soluble sub-fractionated parts from bee (Apis mellifera) venom. Arch. Pharm. Res., 26, 383-388 (2003).

11) Chen HS, Lei J, He X, Wang Y, Wen WW, Wei XZ, Graven-Nielsen T, You HJ, Arendt-Nielsen L. Pivotal involvement of neurogenic mechanism in subcutaneous bee venom-induced inflammation and allodynia in unanesthetized conscious rats. Exp. Neurol., 200, 386-391 (2006).

12) Shin J-H, Park HR, Kim SW, Park C-S, Cho J-H, Park Y-J, Kim SW. The effect of topical FK506 (tacrolimus) in a mouse model of allergic rhinitis. Am. J. Rhinol. Allergy, 26, e71-e75 (2012).

13) Lee HS, Chung SH, Song MY, Kim SS, Shin HD, Shim WJ, Han AR, Lee JS. Effects of bee venom on the maturation of murine dendritic cells stimulated by LPS. J. Ethnopharmacol., 120, 215-219 (2008).

14) Shin SH, Kim YH, Ye MK, Park KK. The effects of bee venom on the proliferation and activation of peripheral blood mononuclear cells. Korean. J. Rhinol., 18, 122-127 (2011).

15) Buku A, Price JA, Mendlowitz M, Masur S. Mast cell degranulating peptide binds to RBL-2H3 mast cell receptors and inhibits IgE binding. Peptides, 22, 1993-1998 (2001).

16) Kim SJ, Shin J-H, Kim SC, Park CK, Kim SW. Preventive effects of oral tolerance on allergic inflammation and airway remodeling in a murine model. Am. J. Rhinol. Allergy, 27, e11-e16 (2013). 